\title{
Possible role of parental age on secretory azoospermia
}

Wahyuning Ramelan

\begin{abstract}
Abstrak
Beberapa parameter (usia, pendidikan, umur orangtua dan kromosom) 59 pria yang menderita azoospermia sekresi telah dibandingkan dengan laki-laki fertil-normal. Azoospermia sekresi dikategorikan sebagai kelainan klinik dengan latar belakang genetik. Telah diketahui bahwa pemunculan sejumlah kelainan genetik yang pertama (de novo) dalam keluarga, dipengaruhi oleh umur orangtua. Dilakukan uji statistik untuk membedakan parameter antara kelompok diteliti dan kelompok pembanding. Umur orangtua (ayah dan ibu) penderita azoospermia terbukti lebih tua daripada umur orangtua pembanding. Hal ini dapat diinterpretasikan sebagai kemungkinan adanya pengaruh faktor umur orangtua terhadap terjadinya azoospermia pada anak laki-laki mereka.
\end{abstract}

\begin{abstract}
Some parameters (age, education and parental aged) in 59 infertile male patients with secretory azoospermia and have had chromosomal examination were studied and compared to the normal fertile male. Secretory azoospermia can be categorized as a clinical entity with genetic background. As already known, de novo patient of some genetic entities in the family, is influenced by parental age. Statistical test were done to differentiate all parameters of both groups. The parental age (matemal and patemal) were significantly higher in the azoospermic as compared to the control group. This finding can be interpreted as the possibility of parental age influence on the occurrence of azoospermia in their son.
\end{abstract}

Keywords: secretory azoospermia, epidemiology, parental age

\section{INTRODUCTION}

Azoospermia is the extreme condition in a man resulted to his failure in reproductive ability, due to the absence of sperm in his semen. This condition could be considered as primary azoospermia if up to the present situation he hadn't had any child through his normal spouse. And it could be called secondary azoospermia, if before the present situation, he had already child/children through his normal fertile spouse. Those considerations are proprosed in analogy to primary amenorrhoe and secondary amenorrhoe. Another category of azoospermia are secretory azoospermia and obstructive azoospermia. In secretory azoospermia, the epididymal duct are patent, and all kinds of product from the testicles can be drain out through the duct. On the other hand, obstructive azoospermia is clear condition, in which an obstruction is present in both epididymal ducts or in the excretory duct, and this condition prevent all kinds of product from the testicle to be secreted from the testicles. A simple test can be done, to differentiate both types of

Department of Medical Biology, Faculty of Medicine, University of Indonesia, Jakarta, Indonesia azoospermia, namely fructose test. A positive fructose test denote to secretory azoospermia, while a negative test exist in the obstruction of epididymal or excretory duct. ${ }^{1}$

Some couples in their reproductive years, had difficulties in their reproduction system and they became infertile couples. About $1 \%$ of such couples, the cause of their infertility is due to azoospermic condition in the male side. Some of the azoospermia patients, especially the secretory one, can be considered as genetically determined such as Klinefelter syndrome, ${ }^{1-4}$ XX-male syndrome, ${ }^{5}$ Kallmann syndrome, ${ }^{1}$ azoospermia with AZF (azoospermia factor)/ DAZ (deleted factor in azoospermia) ${ }^{6}$ etc. All those secretory azoospermia can be categorized as one clinical entity, but with different genetical background as the cause. As we already knew some of the genetic abnormalities are influenced by parental age, such as maternal age in Down syndrome, grand-fathers age of the maternal side in newly mutation X-linked diseases). ${ }^{7,8}$

This paper is aimed mainly to examined wether parental (either paternal or maternal) age had influence in the secretory azoospermic condition in their son. As we know, genetic diseases which are influenced by parental age, means that the longer someone live, the 
more natural radiation he/she got and the more risk that his/her genetic material in the gonads will be influenced to mutation. ${ }^{7}$ And the result of such mutation, if it is really happened, is the occurrence of the genetic disease in his/her child born afterwards. This paper is additional report of previously reported cytogenetic study on azoospermia. ${ }^{4}$

\section{MATERIALS AND METHODS}

Male patients from infertile couples were sent or come to our department (Department of Medical Biology, Faculty of Medicine University of Indonesia). They went through physical examination in correlation with their reproductive system. During those seasons, they were asked about their age, and concerning the previous possibility of infection of their reproductive system. Simple laboratory test (peripheral blood examination, and blood sugar) were done, beside sperm analysis. Sperm examination were done in conform to the WHO laboratory manual for sperm analysis; sperm consentration in ejaculate, sperm viability, sperm motility, abnormal sperm and the fructose test. Patients with secretory azoospermia (azoospermia and positive fructose test), negative history of previous infection and normal laboratory test, then were asked to have chromosome examination. Second sperm analysis were perform prior to or simultaneously with the chromosome examination. During all the seasons, their parental age were asked. To ensure this parameter, parental age were asked in 2 separate occasion. Their educational background (reported in the years length of study) were also questioned. A small part of those azoospermics samples were collected from those who will get married in the near future and found to be azoospermic.

A group of males from couples who came to our department for genetic counseling, who doesn't had any abnormality related to their reproductive system, determined to be the control group. They had children in the range of 1-3. They were considered normal without any problems concerning directly to their own (body), although they had (genetic) problems concerning their family. They were asked the same information as the azoospermics group, eg. age, education and their parental ages. All those information were gathered during their genetics counseling seasons, which usually done in more than one season.

Arithmatic means and standard deviations of all those parameter were calculated. All the results were compared statistically, between the studied (the azoospermic group) and the normal control group.

\section{RESULTS}

Fifty nine azoospermic patients conform to the above condition, were our subject of this study. Their age is in the range of 18-46 years, with mean age of 29.24 years and standard deviation of 6.3 years. Their educational background range from Junior (Primary) High School to university education. This educational background was converted to length of study (in years), 7-18 years, with mean of 13.14 and standard deviation of 2.03 years. Their paternal ages were $27-45$ years (mean 35.25 and standard deviation 4.22 years). The maternal age were 25-41 years (mean 31.02 and standard deviation of 4.04 years). There were 3 persons who were azoospermias and not yet married.

Sixty normal male conform to those condition became control group, with age range 21-45 years and mean age 34.62 and standard deviation 4.41 years. Their educational background is slightly higher than the studied group. The lowest education in the control group was Senior High School (SMU), while the highest is the same in both groups. This educational status range from 12-18, with mean of 14.75 and standard deviation of 1.63 years. The paternal age is in the range of 24-50 years (mean 32.2 and standard deviation of 4.64 years), while for the range of maternal age were 21-42 years (mean 26.53 and standard deviation 4.67 years).

All the calculated figures from the results of this study, were presented in the table 1 .

The results of the cytogenetic examination (chromosome analysis) of this study is the finding of $7(11.9 \%)$ patients with chromosomal aberrations from the 59 azoospermics. In the previous paper ${ }^{4}$ it was reported $6(11.3 \%)$ patients with chromosomal aberrations, out of 53. The chromosomal aberrations reported here consists of 2 patients with $46, \mathrm{XX}$ (XX male), 5 with mosaicism consists further of 2 with $X Y / X O, 2$ with $\mathrm{XXY} / \mathrm{XY}$ and a patient with $\mathrm{XXY} / \mathrm{XX}$. The types of aberrations in both reports are same, with addition of a patient of Klinefelter mosaicism in this report. For more discussion concerning the chromosomal aberrations among the azoospermics, please refer to the previous report. ${ }^{4}$

\section{DISCUSSION}

Viewing from the azoospermia point of view, the studied group were rather old, with age range of 18 46 year. Eleven (nearly $20 \%$ ) patients with azoosper- 
Working table 1. Comparison figures of the parameter from the azoospermics and the normal male control

\begin{tabular}{|c|c|c|c|c|}
\hline Parameter & Azoospermia & Control & t-test & Significancy \\
\hline Number & 59 & 60 & & \\
\hline \multicolumn{5}{|l|}{ Age : } \\
\hline range & $18-46$ & $21-45$ & 5.4 & $P<0.001$ \\
\hline mean & 29.24 & 34.62 & & \\
\hline standard dev. & 6.3 & 4.41 & & \\
\hline \multicolumn{5}{|l|}{ Education : } \\
\hline range & $7-18$ & $12-18$ & 4.7 & $\mathrm{P}<0.001$ \\
\hline mean & 13.14 & 14.75 & & \\
\hline standard dev. & 2.03 & 1.63 & & \\
\hline \multicolumn{5}{|l|}{ Parental age : } \\
\hline paternal: range & $27-45$ & $24-50$ & 3.8 & $\mathrm{P}<0.001$ \\
\hline mean & 35.25 & 32.2 & & \\
\hline standard dev. & 4.22 & 4.64 & & \\
\hline maternal: range & $25-41$ & $21-42$ & 5.8 & $\mathrm{P}<0.001$ \\
\hline mean & 31.02 & 26.53 & & \\
\hline
\end{tabular}

mia were already above 35 year of age. They could be considered 'late comers' in seeking medical help for solving their infertility problem. A few of them came to medical profession after second married or were insisted by their wife. There were still many men/husband, who believed that fertility and infertility were women/wife problem.

The age of the studied group and the control group almost at the same range. The mean age in the control group was higher but the standard deviation was lower. Calculation of $t$ - test result to highly significant difference beetwen both groups. It was clear that the control group was older because most genetics problems in the family usually appears when the parent are become older. The difference strenghthen that both group were actually a different entity, the azoospermic and non-azoospermic (normal/control) group.

Educational background of the azoospermic were significantly lower than the normal male, who seek medical, genetic counseling. Since that counseling information will not gave any direct effect, especially concerning the cure of the (genetic) disease in their family. Thus, only well (higher) educated people will consider that a genetic counseling was still worthwile, especially in the future planning for the family.

Although there were abbout $5 \%$ ( 3 patients) of the azoospermic who were not married, compared to $100 \%$ of married male in the control group, it was believed that this difference is not meaningful.

The parental age of the secretory azoospermic were significantly higher than the parental age of males in the control group. The significant difference were concluded both in the paternal and maternal age. Based on these observations it is speculated that the parental age may had influence in the occurence of the secretory azoospermia in their sons. Further more, that this type of azoospermia may have a genetic influenced. The basic assumption of the parental age influence on the occurrence of certain genetics disease is based on the increase potential of having natural radiation during live, which increased the risk of mutation of their genetic materials in the gonad. ${ }^{7}$ Such mutation, will manifested as the occurrence of a genetic disease in their child, born afterwards. Epidemiologically, the occurrence of such parental age influenced genetic disease run paralel with the increasing of the age. Similar conclusions were also reported in many others genetic disease or abnormalities. eg. Down syndrome influenced by the maternal age, X-linked disease by the age of grand-father of the maternal side. 8,9 The magnitude of is the influence is not yet clear at the present situation. Specific study, especially in the field of molecular (DNA) aspects should be done as well as other epidemiological parameters, before more apropriate and exact conclusion in corelation with parental age, can be drown.

\section{CONCLUSION}

Age, education and parental (maternal and paternal) age of the secretory azoospermia were studied and compared to normal fertile male. All those parameters were significantly different between both groups. Parental age (both maternal and paternal age) of this 
type of azoospermia were higher and significantly different from those of the normal control. The significant higher parental age may be interpreted as firstly, the possibility of the parental age influence on the occurrence of secretory azoospermia in their sons. Secondly, this type of azoospermia may have genetic based.

\section{REFERENCES}

1. Tadjudin MK. Spermatogenesis in azoospermia (Dissertation). Dept. of Medical Biology, Faculty of Medicine, University of Indonesia, 1984.

2. Benirschke K. Cytogenetics in reproduction. In: Jen and Jaffe (eds), Reproductive endocrinology. ${ }^{2 n d}$.ed. Philadelphia, Saunders 1986, p.264-28.

3. Ramelan W. Additional abnormalities of the reproductive organ as indicator for chromosome examination in primary amenorrhoe and azoospermia (Disertation). Fac. of Graduate, University Indonesia, 1993, 2:3-7.

4. Ramelan W. Chromosome aberration in azoospermias. Med J Univ Indon 1993, 2 : 3-7.

5. Grouchy J de, Turleau C. Clinical atlas of human chromosomes. $2^{\text {nd }}$. ed. J Willey \& Sons, New York, 1984, p.396-7.

6. Menke DB, Mutter GL, Page DC. Expression of DAZ, an azoospermia factor candidate, in human spermatogonia. Am J Hum Genet., 1997, 60 : 237-40.

7. Penrose LS. Parental age and mutation. In: Boyer IV (ed). Papers on Human Genetics. Prentice Hall, Englewoods, 1963,270-6.

8. Nora JJ, Fraser FC, Bear J, Greenberg CR, Patterson D, Warburton D. Nora and Fraser Medical Genetics; Principles and Practice. ${ }^{4 t} \mathrm{~h}$. ed. Lea \& Fabiger, Philadelphia, 1994, p.38-43, 241.

9. Vogel F, Motulsky AG. Human genetics : Problems and approaches. $3^{\text {th }}$. ed. Springer Verlag Berlin, 1986,p. 336-41, 355-65. 
Table 1. Data of the azoospermics

\begin{tabular}{|c|c|c|c|c|}
\hline Case nr. & Age & Education & Paternal age & Maternal age \\
\hline 1 & 25 & 15 & 32 & 30 \\
\hline 2 & 46 & 14 & 37 & 37 \\
\hline 3 & 32 & 13 & 32 & 29 \\
\hline 4 & 25 & 12 & 40 & 32 \\
\hline 5 & 28 & 14 & 37 & 32 \\
\hline 6 & 32 & 12 & 34 & 29 \\
\hline 7 & 24 & 12 & 33 & 28 \\
\hline 8 & 21 & 12 & 35 & 29 \\
\hline 9 & 27 & 14 & 33 & 28 \\
\hline 10 & 37 & 15 & 36 & 32 \\
\hline 11 & 25 & 10 & 34 & 33 \\
\hline 12 & 40 & 14 & 33 & 31 \\
\hline 13 & 27 & 14 & 31 & 29 \\
\hline 14 & 19 & 12 & 31 & 26 \\
\hline 15 & 18 & 11 & 41 & 38 \\
\hline 16 & 19 & 12 & 29 & 27 \\
\hline 17 & 26 & 12 & 33 & 25 \\
\hline 18 & 23 & 12 & 37 & 29 \\
\hline 19 & 35 & 12 & 33 & 30 \\
\hline 20 & 27 & 15 & 36 & 29 \\
\hline 21 & 33 & 14 & 37 & 29 \\
\hline 22 & 27 & 14 & 34 & 28 \\
\hline 23 & 29 & 14 & 41 & 36 \\
\hline 24 & 28 & 12 & 31 & 29 \\
\hline 25 & 21 & 14 & 31 & 28 \\
\hline 26 & 30 & 14 & 29 & 30 \\
\hline 27 & 28 & 12 & 34 & 31 \\
\hline 28 & 25 & 15 & 34 & 29 \\
\hline 29 & 23 & 12 & 29 & 26 \\
\hline 30 & 25 & 11 & 27 & 26 \\
\hline 31 & 30 & 12 & 39 & 36 \\
\hline 32 & 29 & 17 & 32 & 25 \\
\hline 33 & 27 & 12 & 29 & 25 \\
\hline 34 & 32 & 14 & 42 & 35 \\
\hline 35 & 40 & 15 & 45 & 40 \\
\hline 36 & 26 & 14 & 30 & 26 \\
\hline 37 & 38 & 15 & 37 & 33 \\
\hline 38 & 24 & 15 & 39 & 33 \\
\hline 39 & 35 & 15 & 44 & 40 \\
\hline 40 & 26 & 14 & 37 & 32 \\
\hline 41 & 40 & 12 & 31 & 25 \\
\hline 42 & 35 & 14 & 37 & 29 \\
\hline 43 & 37 & 14 & 38 & 35 \\
\hline 44 & 36 & 18 & 41 & 37 \\
\hline 45 & 38 & 14 & 29 & 28 \\
\hline 46 & 31 & 18 & 45 & 41 \\
\hline 47 & 24 & 7 & 40 & 36 \\
\hline 48 & 18 & 12 & 39 & 31 \\
\hline 49 & 29 & 15 & 38 & 35 \\
\hline 50 & 43 & 12 & 36 & 31 \\
\hline 51 & 37 & 15 & 32 & 27 \\
\hline 52 & 32 & 12 & 36 & 27 \\
\hline 53 & 30 & 12 & 39 & 34 \\
\hline 54 & 27 & 9 & 37 & 32 \\
\hline 55 & 31 & 13 & 36 & 32 \\
\hline 56 & 28 & 10 & 32 & 30 \\
\hline mean & 29.24 & 13.14 & 35.25 & 31.02 \\
\hline standard deviation & 6.3 & 2.03 & 4.22 & 4.04 \\
\hline
\end{tabular}


Table 2. Data of 60 normal male

\begin{tabular}{|c|c|c|c|c|}
\hline Case nr. & Age & Education & Paternal age & Maternal age \\
\hline 1 & 36 & 14 & 34 & 29 \\
\hline 2 & 33 & 12 & 32 & 27 \\
\hline 3 & 38 & 14 & 38 & 32 \\
\hline 4 & 35 & 15 & 31 & 24 \\
\hline 5 & 37 & 17 & 38 & 33 \\
\hline 6 & 31 & 14 & 41 & 37 \\
\hline 7 & 21 & 14 & 40 & 34 \\
\hline 8 & 27 & 15 & 37 & 31 \\
\hline 9 & 32 & 12 & 29 & 23 \\
\hline 10 & 33 & 15 & 35 & 31 \\
\hline 11 & 36 & 14 & 34 & 29 \\
\hline 12 & 37 & 14 & 39 & 34 \\
\hline 13 & 40 & 15 & 29 & 22 \\
\hline 14 & 40 & 17 & 29 & 24 \\
\hline 15 & 40 & 15 & 41 & 37 \\
\hline 16 & 33 & 12 & 35 & 31 \\
\hline 17 & 26 & 13 & 38 & 29 \\
\hline 18 & 34 & 15 & 29 & 25 \\
\hline 19 & 35 & 12 & 50 & 42 \\
\hline 20 & 32 & 14 & 34 & 27 \\
\hline 21 & 33 & 14 & 37 & 32 \\
\hline 22 & 43 & 15 & 39 & 32 \\
\hline 23 & 31 & 14 & 34 & 27 \\
\hline 24 & 26 & 16 & 34 & 27 \\
\hline 25 & 37 & 16 & 28 & 24 \\
\hline 26 & 29 & 17 & 29 & 22 \\
\hline 27 & 38 & 18 & 34 & 26 \\
\hline 28 & 45 & 17 & 27 & 21 \\
\hline 29 & 37 & 16 & 29 & 23 \\
\hline 30 & 33 & 12 & 28 & 21 \\
\hline 31 & 36 & 13 & 31 & 24 \\
\hline 32 & 40 & 14 & 31 & 25 \\
\hline 33 & 37 & 13 & 34 & 26 \\
\hline 34 & 33 & 15 & 34 & 25 \\
\hline 35 & 25 & 17 & 29 & 23 \\
\hline 36 & 32 & 17 & 37 & 29 \\
\hline 37 & 39 & 14 & 31 & 23 \\
\hline 38 & 34 & 18 & 30 & 23 \\
\hline 39 & 37 & 15 & 37 & 28 \\
\hline 40 & 39 & 15 & 40 & 32 \\
\hline 41 & 33 & 14 & 32 & 24 \\
\hline 42 & 34 & 17 & 36 & 27 \\
\hline 43 & 37 & 17 & 29 & 23 \\
\hline 44 & 33 & 15 & 38 & 30 \\
\hline 45 & 38 & 17 & 32 & 26 \\
\hline 46 & 37 & 14 & 39 & 29 \\
\hline 47 & 32 & 15 & 32 & 23 \\
\hline 48 & 31 & 14 & 27 & 21 \\
\hline 49 & 31 & 14 & 31 & 22 \\
\hline 50 & 32 & 15 & 28 & 22 \\
\hline 51 & 31 & 13 & 27 & 22 \\
\hline 52 & 34 & 15 & 29 & 23 \\
\hline 53 & 35 & 12 & 30 & 24 \\
\hline 54 & 35 & 15 & 30 & 23 \\
\hline 55 & 40 & 15 & 37 & 27 \\
\hline 56 & 32 & 12 & 32 & 24 \\
\hline 57 & 38 & 14 & 24 & 20 \\
\hline 58 & 30 & 14 & 27 & 23 \\
\hline mean & 34.62 & 14.75 & 32.2 & 26.53 \\
\hline standard deviation & 4.41 & 1.63 & 4.64 & 4.67 \\
\hline
\end{tabular}

